\begin{tabular}{|c|c|}
\hline \multirow{3}{*}{ 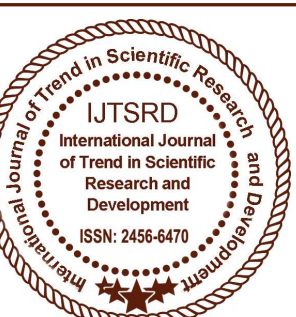 } & $\begin{array}{l}\text { International Journal of Trend in Scientific } \\
\text { Research and Development (IJTSRD) }\end{array}$ \\
\hline & International Open Access Journal \\
\hline & ISSN No: 2456 - 6470 | www.ijtsrd.com | Volume - 2 | Issue - 5 \\
\hline
\end{tabular}

\title{
A Clinical Study on Vyaghritailanasya in The Management of Putinasa
}

\author{
Dr. Abhijith H N \\ Associate Professor, Department of ShalakyaTantra, \\ S.D.M.College of Ayurveda and Hospital, Hassan, Karnataka, India
}

\begin{abstract}
Twenty patients of putinasa were diagnosed and registered for the clinical study irrespective of sex, socio-economic status and religion with an aim to know the efficacy of vyaghritailanasya. The study was divided into two groups viz Group A and Group B. Group A patients were treated with vyaghritailanasya for 7 days and group B patients were treated with tilatailanasya for 7 days. To present the study in a scientific manner 4 criterias were made for assessment and stastical evaluation. Finally favourable results were found. The signs and symptoms were reduced and the results were significantly effective.

Keywords: Putinasa, Nasya, Vyaghritaila, Tilataila, Sinusitis, Atrophic rhinitis, Vyaghri, Danti, Vacha, Shigru, Surasa, Vyosha, Saindhava.
\end{abstract}

Means, it is a condition where there is bad or foul smell from the nose4. Though the science is advanced the disease putinasa does not have a permanent solution, hence the present clinical research work is planned to find out a remedy.

\section{NEED FOR THE STUDY}

In this regard while exploring ayurvedic classics, we come across few simple techniques and medicaments in the treatment of Putinasa. Nasya karma with Vyaghri Taila5is one among them. Nasya karma is considered as a prime treatment modality in all types of nasarogaand also in Putinasa .

\section{INTRODUCTION}

Putinasa is one among the 31 types of nasarogas explained in the classics. It is one of the common clinical conditions found in day to day general as well as shalakya practice. It presents with foul smell from the nose and mouth as one of its cardinal features 1 and its occurrence is found in both sexes and in all age groups.

The cardinal features of putinasa include foul smell from the nose and mouth This condition is becoming increasingly prevalent due to exposure to avashyaya (fog), rajo (dust), dhuma (smoke), asathymagandha (smell) and vayusevanaetc, causes vitiation in gala and talumoola by dearrangingkapha, pitta and raktha dosas 2 . Nose being the outer and exposed structure becomes victim for various pathologic changes. 'Putirdurgandonasayahanasikabhavo rogaha'3,

Yogaratnakara has described 'Vyaghri Taila Nasya' in the management of Putinasa. This technique is easy to perform and the medicaments are easily available and economical. Hence, it is selected for the present clinical research work.

This work is intended to know the efficacy of the trial drug. For this purpose tilataila is taken for control group for comparative assessment.

There are various references regarding the usage of tilataila as a base for different tailas used in the management of putinasa. Tilataila possess qualities like vatahara, tiksna, vyavayi, sukshma and ushna. Considering these therapeutic values of tilataila it has been taken as a control drug in this study.

\section{MATERIALS AND METHODS}

The main objective of the study was to test the efficacy of vyaghritailanasya in the management of Putinasa. A total of forty patients were selected randomly from the outpatient department of Shalakya Tantra, SDM Ayurveda hospital Hassan for the study. 


\section{Inclusion criteria}

Patients presenting with the classical features of putinasa between the age group of 7 to $80 \mathrm{yrs}$ were selected. Patients were selected irrespective of sex, occupation, religion, socio - economic status and duration of illness.

\section{Exclusion criteria}

Patients below 7 years and above 80 years of age were excluded. Malignant lesions.

Specific acute infective lesions like T. B, leprosy, syphilis etc. Associated with intracranial complications like cerebrospinal rhinorrhoea 6 .

\section{Study Design:}

Patients were divided into 2 groups. i.e., Group A and Group B.

Group A - Vyaghritailanasya was admnistred for seven days, 6 drops in each nostril, once daily in the morning before food.

Group B - Nasya with tilataila for seven days was admnistred, 6 drops in each nostril, once daily in the morning before food.

Both groups were followed at regular intervals of 1 month for a period of two months.

Drugs used- Vyaghritaila, tilataila

The following are the drugs used in the study.

(VyaghriTaila)

Vyaghri

Danti

Vacha

Shigru

Surasa

Vyosha (Pippali, Maricha, Shunti)

Saindhava

Tilataila

\section{OBSERVATIONS AND RESULTS}

Age wise distribution of patients showed that 8 patients $(40 \%)$ were in the age group of $7-30 \mathrm{yrs}, 10$ patients $(50 \%)$ were in the age group of $31-45$ years and 02 patients $(10 \%)$ were between the age of group $46-80 y r s$.

Incidence of age in patients with putinasa is more in $31-45(50 \%)$ age group in present study.

Out of 20 cases, incidence of putinasais observed in 09 male $(45 \%)$ and in 11 female $(55 \%)$ patients.
Incidence of sex in patients with putinasa is more in females $(55 \%)$ in present study.

Among 20 patients of putinasa, $20(100 \%)$ of patients have foul smell from the breath, $07(35 \%)$ have subjective symptoms, $13(65 \%)$ have objective symptoms, as foul smell in their breath, 15 (75\%) of patients have nasal discharge, $07(35 \%)$ have nasal blockage, and 07 (35\%) have variations from normal $\mathrm{X}$ - Ray.

\section{RESULTS}

Table No. 22Showing the' $t$ ' test results of the difference between the means of the two dependent samples (before and after treatment) in reduction of foul smell in breath in Group A and Group B.

\begin{tabular}{|c|c|c|c|c|c|c|c|c|c|c|}
\hline \multirow{2}{*}{\multicolumn{2}{|c|}{$\begin{array}{l}\text { Foul smell in } \\
\text { breath }\end{array}$}} & \multicolumn{2}{|c|}{$\begin{array}{l}\text { Mean } \\
\text { score }\end{array}$} & \multirow{2}{*}{$\begin{array}{l}\text { Reducti } \\
\text { on in } \\
\text { mean } \\
\text { score }\end{array}$} & \multirow{2}{*}{$\begin{array}{c}\% \text { of } \\
\text { reductio } \\
n \text { in } \\
\text { mean } \\
\text { score }\end{array}$} & \multirow{2}{*}{$\begin{array}{c}\text { S.D } \\
\text { of } \\
\text { mea } \\
n\end{array}$} & \multirow{2}{*}{$\begin{array}{l}\text { S.E of } \\
\text { mean }\end{array}$} & \multirow{2}{*}{$\begin{array}{l}d \\
f\end{array}$} & \multirow{2}{*}{$\begin{array}{c}\text { 't' } \\
\text { Valu } \\
\mathrm{e}\end{array}$} & \multirow{2}{*}{$\begin{array}{c}\text { 'p' } \\
\text { Value }\end{array}$} \\
\hline & & BT & AT & & & & & & & \\
\hline \multirow{3}{*}{$\begin{array}{l}G \\
R \\
O \\
U \\
P\end{array}$} & $\begin{array}{l}\text { After } 7 \\
\text { days of } \\
\text { treatmen } \\
t\end{array}$ & $\begin{array}{l}1 . \\
7\end{array}$ & $\begin{array}{l}0 . \\
4\end{array}$ & 1.3 & 76.47 & $\begin{array}{c}0.699 \\
2\end{array}$ & $\begin{array}{c}0.221 \\
1\end{array}$ & 9 & $\begin{array}{c}1.80 \\
9\end{array}$ & $<0.2$ \\
\hline & $\begin{array}{l}\text { Follow up } \\
\text { after } 1 \\
\text { month }\end{array}$ & $\begin{array}{l}1 . \\
7\end{array}$ & $\begin{array}{c}0 . \\
2\end{array}$ & 1.5 & 88.23 & $\begin{array}{c}0.421 \\
6\end{array}$ & $\begin{array}{c}0.133 \\
3\end{array}$ & 9 & $\begin{array}{c}1.50 \\
0\end{array}$ & $<0.2$ \\
\hline & $\begin{array}{l}\text { Follow up } \\
\text { after } 2 \\
\text { month }\end{array}$ & $\begin{array}{l}1 . \\
7\end{array}$ & $\begin{array}{l}0 . \\
3\end{array}$ & 1.4 & 82.35 & $\begin{array}{c}0.674 \\
9\end{array}$ & $\begin{array}{c}0.213 \\
4\end{array}$ & 9 & $\begin{array}{c}1.40 \\
5\end{array}$ & $<0.2$ \\
\hline & & & & & & & & & & \\
\hline \multirow{3}{*}{$\begin{array}{l}G \\
R \\
O \\
U \\
P\end{array}$} & $\begin{array}{l}\text { After } 7 \\
\text { days of } \\
\text { treatmen } \\
t\end{array}$ & $\begin{array}{l}1 . \\
6\end{array}$ & $\begin{array}{l}0 . \\
5\end{array}$ & 1.1 & 68.75 & $\begin{array}{c}0.707 \\
1\end{array}$ & $\begin{array}{c}0.223 \\
6\end{array}$ & 9 & $\begin{array}{c}2.23 \\
6\end{array}$ & $<0.1$ \\
\hline & $\begin{array}{l}\text { Follow up } \\
\text { after } 1 \\
\text { month }\end{array}$ & $\begin{array}{l}1 . \\
6\end{array}$ & $\begin{array}{l}0 . \\
3\end{array}$ & 1.3 & 81.25 & $\begin{array}{c}0.483 \\
0\end{array}$ & $\begin{array}{c}0.152 \\
7\end{array}$ & 9 & $\begin{array}{c}1.96 \\
4\end{array}$ & $<0.1$ \\
\hline & $\begin{array}{l}\text { Follow up } \\
\text { after } 2 \\
\text { month }\end{array}$ & $\begin{array}{l}1 . \\
6\end{array}$ & $\begin{array}{l}0 . \\
5\end{array}$ & 1.1 & 68.75 & $\begin{array}{c}0.707 \\
1\end{array}$ & $\begin{array}{c}0.223 \\
6\end{array}$ & 9 & $\begin{array}{c}2.23 \\
6\end{array}$ & $<0.1$ \\
\hline
\end{tabular}

In group $A$, the reduction in mean foul smell in breath is,

$>$ Before and after treatment shows changes from 1.7 to 0.4 showing a reduction of $1.3(76.47 \%)$ which is statistically significant at the level of $\mathrm{p}<0.2$,

Changes after 1st month follow up is from 1.7 to 0.2 showing a reduction of $1.5(88.23 \%)$ which is statistically significant at the level of $\mathrm{p}<0.2$ and

$>$ Changes after 2nd month follow up is from 1.7 to 0.3 showing a reduction of $1.4(82.35 \%)$ which is statistically significant at the level of $\mathrm{P}<0.2$.

In group $B$, the reduction in mean foul smell in breath is, 
$>$ Before and after treatment shows changes from 1.6 to 0.5 showing a reduction of $1.1(68.75 \%)$ which is statistically significant at the level of $\mathrm{P}$ $<0.1$.

Changes after 1st month follow up is from 1.6 to 0.3 showing a reduction of $1.3(81.25 \%)$ which is statistically significant at the level of $\mathrm{P}<0.1$ and

Changes after 2nd month follow up is from 1.6 to 0.5 showing a reduction of $1.1(68.75 \%)$ which is statistically significant at the level of $\mathrm{P}<0.1$.

\section{DISCUSSION AND CONCLUSION:}

Nidanas explained in Ayurvedic classics are acting as initiating or precipitating factor for putinasa. Viharasambhandinidanas like exposure to raja, dhooma, sheetavayu and nidanarthakararoga like pratishyayahave a significant role in the onset of putinasa.

Samprapti of putinasa is complex, as various known, unknown, exogenous, or endogenous etiological factors are responsible for pathological process.

Prevalence of putinasa is more in females.

Family history is insignificant in causing putinasa.
Vyaghritailanasya is effective than tilataila in reliving the severity of disease.

Nasya with tilataila showedan average improvement / relief from the symptoms but incidence of recurrence is observed mostly during follow up.

By comparing both groups, Group A patients those administered with vyaghritailanasyashowed significant improvement / relief in the management of putinasa.

Hence the efficacy of vyaghritailanasya in the management of putinasa is proved effective.

\section{REFERENCES:}

1. M. N $58 / 2$

2. B. $\mathrm{P} 65 / 6$

3. Sabdhakalpadhrumavol 3

4. Su. Utt $22 / 7$

5. Y. R apararoganamchikitsa $/ 48$

6. A short text book of $\mathrm{E} \mathrm{N} \mathrm{T}$ diseases. K. B. Bhargava, S. K. Bhargava, T. M S 